\title{
Synthesis of Boc-protected bicycloproline
}

\author{
Sujeewa Ranatunga ${ }^{\dagger}$ and Juan R. Del Valle ${ }^{\ddagger}{ }^{*}$ \\ † Department of Chemistry and Biochemistry, New Mexico State University, Las Cruces, NM 88003 \\ ‡ Drug Discovery Department, Moffitt Cancer Center, 12902 Magnolia Drive, Tampa, FL 33647, \\ USA
}

\begin{abstract}
The synthesis of a highly constrained quaternary carbocyclic $\alpha$-amino acid, (+)- $N$-Bocbicycloproline, has been achieved starting from sodium cyclopentadienylide. Key steps include a rhodium-catalyzed nitrenoid $\mathrm{C}-\mathrm{H}$ insertion to install the tert-alkylamine and a ring-closing metathesis reaction to form the pyrrolidine ring.
\end{abstract}

Structure-based peptidomimetic drug design has been aided by the development of synthetic methods toward various rigidified amino acids (Fig. 1). Cyclic residues and quaternary $\alpha$-amino acids (or $\alpha, \alpha$-dialkylated amino acids) have garnered special interest due to their ability to restrict the $\psi, \varphi$, and $\omega$ torsional angles of the peptide backbone. ${ }^{1}$ While proline is the only canonical proteinogenic amino acid harboring a cyclic constraint, various other cyclic and quaternary amino acids have been found in nature, often as components of biologically active peptides with well-defined secondary structures. ${ }^{2}$ The conformational and biological properties of many of these residues have been the impetus for a number of synthetic studies. $2 \mathrm{~d}, 3$

In connection with our interest in $\alpha$-amino acids that may have a profound influence on the amide backbone (cis-trans) rotameric equilibrium, we selected bicycloproline

(octahydrocyclopenta[b]pyrrole-6a-carboxylic acid, 1) as an initial target (Fig. 2). Recently, Trauner and co-workers reported a strategy toward bicycloproline starting from Meyer's lactam, providing a potential precursor to $1 .{ }^{4}$ Although the synthesis of racemic $\mathbf{1}$ and related structural motifs has been reported in the literature, ${ }^{5}$ we describe herein the first synthesis of enantiopure N-protected bicycloproline from a readily available chiral progenitor.

The octahydrocyclopenta[b]pyrrole core of bicycloproline comprises a substituted cyclopentane ring fused to pyrrolidine. Assuming that the heterocyclic ring could be formed at a late stage, our strategy centered on the synthesis of a cyclopentane harboring a quaternary aminated carbon. We envisioned that the tert-alkylamino group could be installed via intramolecular $\mathrm{C}-\mathrm{H}$ insertion of an oxycarbonylnitrene onto an appropriately substituted tertiary carbon. ${ }^{6}$ In our search for a useful cyclopentanoid substrate, we settled on 2benzyloxymethylcyclopent-3-enol for its pattern of substitution and its availability from cyclopentadiene in optically pure form. ${ }^{7}$

The synthesis of (2R,3S)-2-benzyloxymethylcyclopent-3-enol was carried out following the modification by Gellman and co-workers. ${ }^{8}$ We prepared $\mathbf{2}$ in multi-gram batches over three steps ${ }^{9}$ and introduced the primary carbamate with trichloroacetylisocyanate to give $\mathbf{3}$ in $85 \%$

\footnotetext{
* Corresponding author. Tel.: +1 813745 6142. juan.delvalle@moffitt.org (J. R. D. Valle).

Supplementary data: Supplementary data (experimental procedures, complete spectral data, copies of NMR spectra for new compounds, and X-ray and for 23) associated with this article can be found, in the online version, at doi:10.1016/j.tetlet.2009.03.092.
} 
yield (Scheme 1). We explored a number of different conditions for the ensuing C-H insertion using $\mathrm{Rh}(\mathrm{II})$ catalysts (DuBois conditions6d) as well as the $\mathrm{Ag}(\mathrm{I})$-catalyzed conditions recently reported by $\mathrm{He}$ and Cui6e. In our hands, $\mathrm{Ag}(\mathrm{I})$ catalysis failed to give appreciable amounts of insertion products. In conjunction with various $\mathrm{Rh}$ (II) catalysts, different permutations of oxidant $\left(\mathrm{PhI}(\mathrm{OAc})_{2}, \mathrm{PhI}=\mathrm{O}\right)$, base $\left(\mathrm{K}_{2} \mathrm{CO}_{3}, 2\right.$,6-lutidine, $\left.\mathrm{MgO}\right)$, solvent (toluene, $\mathrm{DCM}, 1,2-$ DCE, benzene), and temperature were investigated. Under optimized conditions, the desired product (4) was obtained in 35\% yield after purification. In addition, we isolated $13 \%$ of the isomeric product $\mathbf{5}$, as well as a small amount of aziride $\mathbf{6}$. In nearly every case screened, we observed an approximately 2:1 ratio of tertiary:secondary $\mathrm{C}-\mathrm{H}$ insertion products (4:5). These results are consistent with the enhanced reactivity exhibited by more substituted carbons toward $N$-acyloxynitrenoids. ${ }^{6 \mathrm{~d}, 10}$

In an effort to parse the factors contributing to reaction regioselectivity, we synthesized a variety of other substrates (Scheme 2). Reactions carried out with saturated substrate 7 under optimized conditions resulted in lower conversion and in $32 \%$ yield of the desired product, but no appreciable insertion at the secondary $\mathrm{C}-\mathrm{H}$ bond. Substrates $\mathbf{9}$ and $\mathbf{1 1}$ were prepared in an attempt to compel insertion at the tertiary carbon center. Reaction of $\mathbf{9}$ under optimized conditions led to exclusive insertion at the ethereal carbon to give $N$-acyloxyaminal $\mathbf{1 0}$ as the only major product. This result was unexpected in light of the well-established preference for five-membered cyclic carbamate formation in related systems and is probably due to the blocking effect of the $O$-TBDPS group on the $\beta$-face of the cyclopentane ring. When the reaction was carried out with the less sterically demanding $O$-MOM derivative 11, the sixmembered $N$-acyloxyaminal (12) was similarly obtained as the major product along with desired spirocycle 13. The appreciable formation of products $\mathbf{1 0}$ and $\mathbf{1 2}$ in these reactions suggests that ether substituents act as strong activators of the geminal $\mathrm{C}-\mathrm{H}$ bonds. Reaction of sulfamate ester $\mathbf{1 4}$ under similar $\mathrm{Rh}(\mathrm{II})$-catalyzed conditions gave $60 \%$ yield of tricyclic aziridine derivative $\mathbf{1 5}$.

Although compounds 4,8 , and 13 represented useful intermediates for our synthesis, we opted to continue with cyclopentene $\mathbf{4}$ due to step economy and higher overall yields. Compound $\mathbf{4}$ was saturated by hydrogenation and the cyclic carbamate allylated with KHMDS and allyl bromide in $82 \%$ yield (Scheme 3). Alkaline hydrolysis of the carbamate gave 17 in good yield, but Boc-protection of the resulting amine met with difficulties, providing large amounts of $\mathbf{1 6}$ in addition to 18. Presumably, Boc-protection is followed by rapid attack of the vicinal hydroxyl group to give the cyclic precursor. Moreover, we found compound $\mathbf{1 8}$ to be unstable toward subsequent oxidation conditions, and also unstable upon storage at room temperature (neat), resulting in recovery of additional $\mathbf{1 6}$.

As an alternative to $N$-acyloxy protection, the secondary amine was benzylated under standard conditions and subjected to Swern oxidation to give ketone 19. Wittig methylenation then provided diene $\mathbf{2 0}$ in $88 \%$ yield. In consideration of the free amine group in $\mathbf{2 0}$, the subsequent $\mathrm{RCM}$ reaction required some optimization. We found that pyrroline formation occured smoothly in $78 \%$ yield using $7 \mathrm{~mol} \%$ of Grubbs' 2 nd generation catalyst (added in two portions) in toluene at $60{ }^{\circ} \mathrm{C}$. Treatment of 21 with Perlman's catalyst and $\mathrm{H}_{2}$ resulted in saturation and concomitant debenzylation. This was followed by Boc-protection of the crude aminoalcohol to afford 22. Finally, oxidation using sodium chlorite, bleach, and catalytic TEMPO provided $\mathrm{N}$-Boc-bicycloproline (23) in $75 \%$ yield. The ${ }^{1} \mathrm{H}$ NMR spectrum of $\mathbf{2 3}$ is consistent with that of the expected structure but is complicated by the presence of cis and trans carbamate rotamers. Compound 23 was recrystalized out of DCM/hexane for analysis by X-ray diffraction. The crystal structure we obtained confirmed the structure and relative stereochemistry of synthetic (+)-N-Boc-bicycloproline (Scheme 4). ${ }^{11}$ 
In summary, we have utilized $(2 R, 3 S)$-2-benzyloxymethylcyclopent-3-enol as a practical starting material for the synthesis of bicycloproline. The key steps in our synthesis are a Rh (II)-catalyzed nitrenoid insertion reaction to provide the tert-alkylamine and a Grubbs' ringclosing metathesis to form the pyrrolidine ring. We are currently investigating the regioselectivity of $\mathrm{C}-\mathrm{H}$ insertions in polyfunctional substrates for the synthesis of other complex amino acids. The incorporation of bicycloproline into host structures and its effects on peptide conformation will be reported in due course.

\section{Supplementary Material}

Refer to Web version on PubMed Central for supplementary material.

\section{Acknowledgments}

We thank Leticia Montoya (New Mexico State University) and the Scripps Center for Mass Spectrometry for mass analysis of all compounds, and Dr. Eileen Duesler (University of New Mexico) for X-ray studies on compound 23.

This work was supported by a grant from the National Institute of General Medical Sciences (NIH 1SC2AI081526-01).

\section{References and notes}

1. (a) Venkatraman J, Shankaramma SC, Balaram P. Chem Rev 2001;101:3131-3152. [PubMed: 11710065] (b) Toniolo C, Crisma M, Formaggio F, Peggion C. Biopolymers 2001;60:396-419. [PubMed: 12209474] (c) Hruby VJ. Acc Chem Res 2001;34:389-397. [PubMed: 11352717] (d) Gibson SE, Guillo N, Tozer MJ. Tetrahedron 1999;55:585-615. (e) Scheraga HA. Chem Rev 1971;71:195. [PubMed: 4927987] (f) Casanovas J, Jimenez AI, Cativiela C, Nussinov R, Aleman C. J Org Chem 2008;73:644-651. [PubMed: 18081347] (g) Casanovas J, Nussinov R, Aleman C. J Org Chem 2008;73:4205-4211. [PubMed: 18465898] (h) Goodman M, Shao H. Pure App Chem 1996;68:1303-1308. (i) Tanaka M. Chem Pharm Bull 2007;55:349-358. [PubMed: 17329870] (j) Hanessian S, McNaughtonSmith G, Lombart HG, Lubell WD. Tetrahedron 1997;53:12789-12854. (k) Karle IL. Biopolymers 2001;60:351-365. [PubMed: 12115146]

2. (a) Whitmore, L.; Wallace, BA. Handbook of Biologically Active Peptides. Kastin, AJ., editor. Elsevier; Burlington: 2006. p. 83-88. (b) Mauger AB. J Nat Prod 1996;59:1205-1211. [PubMed: 8988607] (c) He HY, Janso JE, Yang HY, Bernan VS, Lin SL, Yu K. J Nat Prod 2006;69:736-741. [PubMed: 16724832] (d) Ohfune Y, Shinada T. Eur J Org Chem 2005:5127-5143. (e) Fietzek PP, Kuhn K. Mol Cell Biochem 1975;8:141-157. [PubMed: 171554]

3. For reviews on the synthesis of quaternary $\alpha$-amino acids see: (a) Cativiela C, Diaz-de-Villegas MD. Tetrahedron: Asymmetry 1998;9:3517-3599. (b) Cativiela C, Diaz-de-Villegas MD. Tetrahedron: Asymmetry 2000;11:645-732. (c) Cativiela C, Diaz-de-Villegas MD. Tetrahedron: Asymmetry 2007;18:569-623. (d) Calaza MI, Cativiela C. Eur J Org Chem 2008:3427-3448. (e) Vogt H, Brase S. Org Biomol Chem 2007;5:406-430. [PubMed: 17252120]

4. Dorsey AD, Barbarow JE, Trauner D. Org Lett 2003;5:3237-3239. [PubMed: 12943396]

5. (a) Turner PG, Donohoe TJ, Cousins RPC. Chem Comm 2004:1422-1423. [PubMed: 15179495] (b) Belanger G, April M, Dauphin E, Roy S. J Org Chem 2007;72:1104-1111. [PubMed: 17288364] (c) Ohfune Y, Demura T, Iwama S, Matsuda H, Namba K, Shimamoto K, Shinada T. Tetrahedron Lett 2003;44:5431-5434. (d) Overman LE, Tellew JE. J Org Chem 1996;61:8338-8340. [PubMed: 11667832]

6. For leading references on insertion reactions of $\mathrm{N}$-acyloxy nitrenes see: (a) Lwowski, W. Nitrenes. Lwowski, W., editor. Interscience; New York: 1970. p. 1-11. (b) Meth-Cohn O. Acc Chem Res 1987;20:18-27. (c) Davies HML, Long MS. Angew Chem, Int Ed 2005;44:3518-3520. (d) Espino CG, Du Bois J. Angew Chem, Int Ed 2001;40:598-600. (e) Cui Y, He C. Angew Chem, Int Ed 2004;43:4210-4212.

7. Biggadike K, Borthwick AD, Evans D, Exall AM, Kirk BE, Roberts SM, Stephenson L, Youds P. J Chem Soc, Perkin Trans 1988;1:549-554.

8. Woll MG, Fisk JD, LePlae PR, Gellman SH. J Am Chem Soc 2002;124:12447-12452. [PubMed: 12381185] 
9. We used (-)Ipc 2 BH to prepare the $(2 S, 3 R)$ isomer of $\mathbf{2}$ as described in Ref. 8. The enantiomeric purity of 2 (>95:5) was assessed by conversion to the Mosher ester and analysis by NMR.

10. Li Z, Capretto DA, Rahaman R, He C. Angew Chem, Int Ed 2007;46:5184.

11. See Supplementary data. 

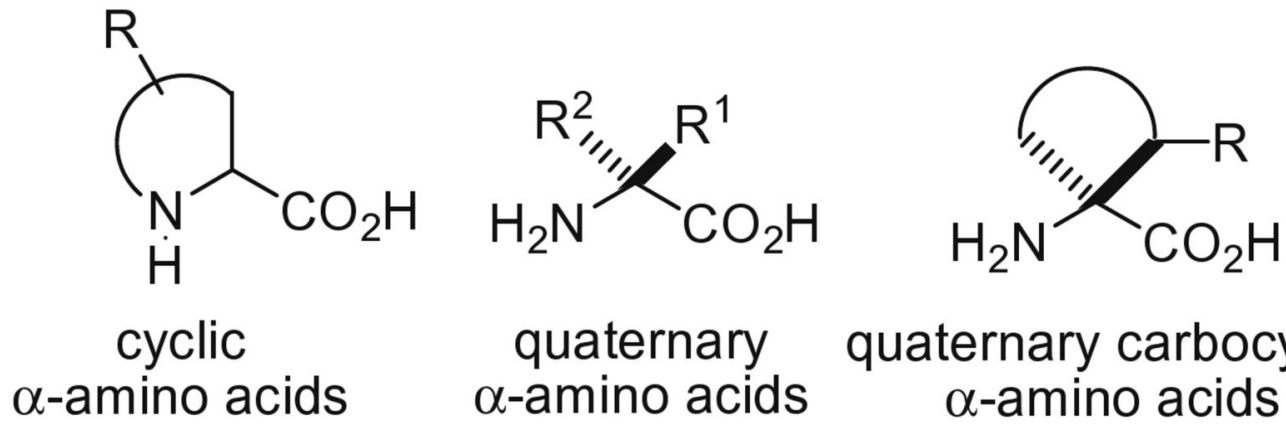

\section{quaternary $\alpha$-amino acids}

quaternary carbocyclic $\alpha$-amino acids

Figure 1.

General structures of some constrained $\alpha$-amino acids. 


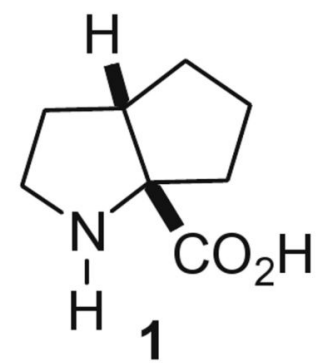

bicycloproline

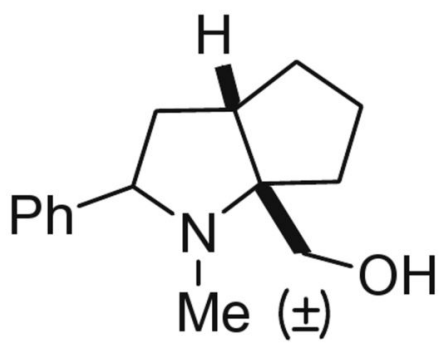

Belanger et al.

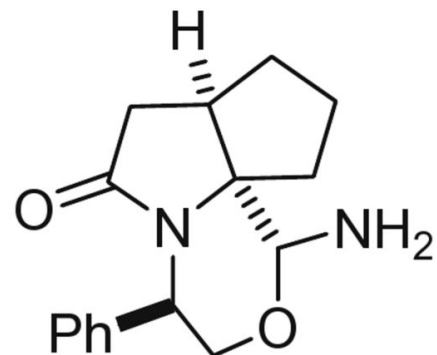

Trauner et al.

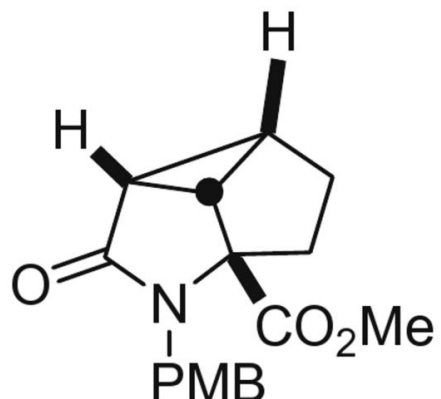
PMB

Ohfune et al.

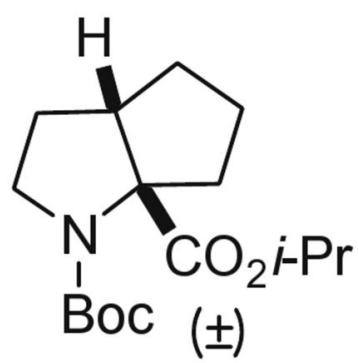

Donohoe et al.

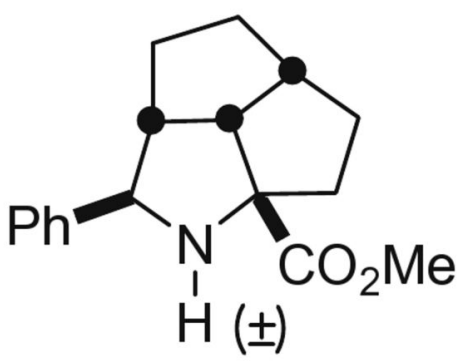

Overman et al.

Figure 2.

Bicycloproline and related structures. 

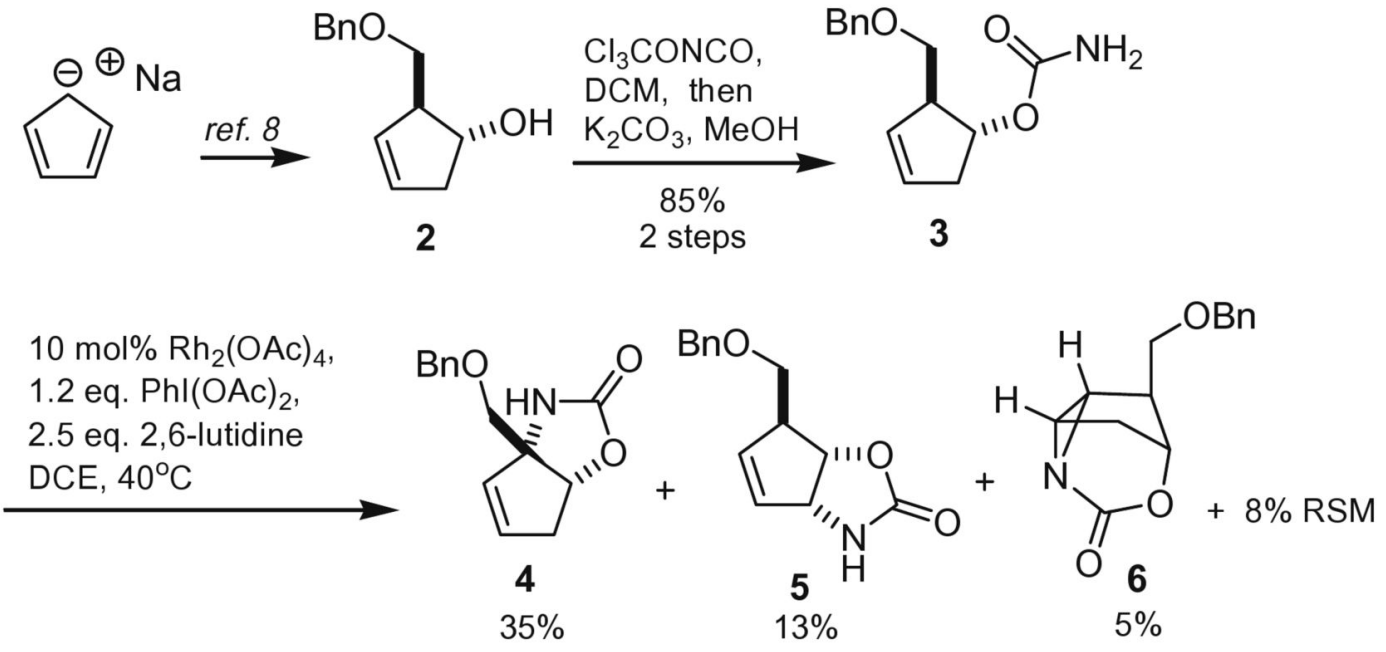

Scheme 1.

Synthesis of 4 (RSM = recovered starting material). 


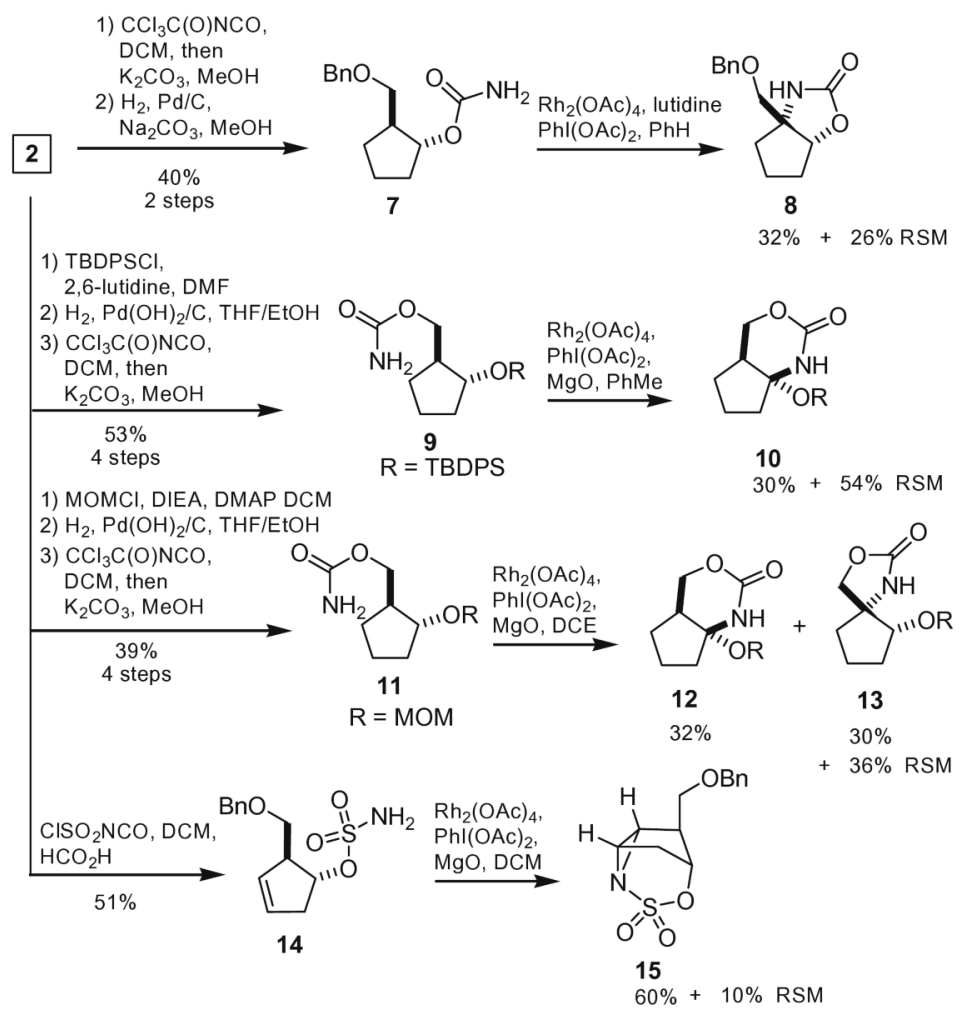

Scheme 2.

Selectivity of $\mathrm{C}-\mathrm{H}$ insertion in related substrates. 


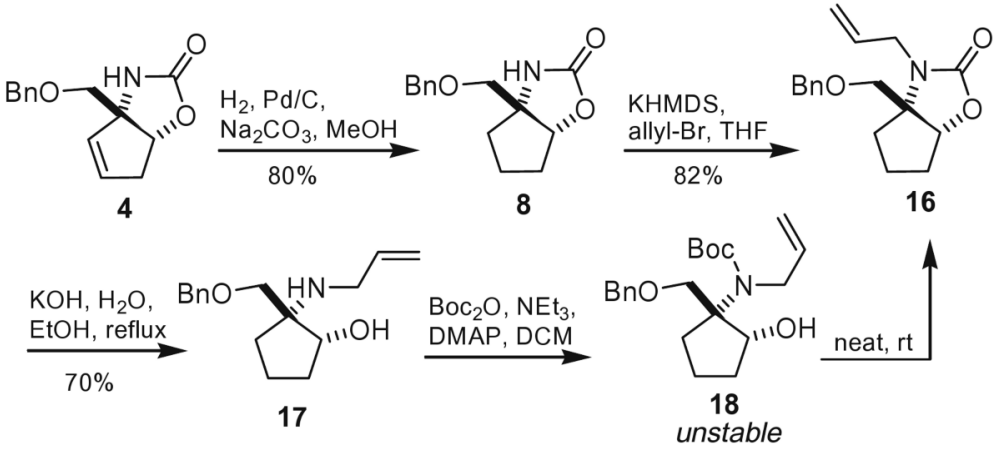

Scheme 3.

Synthesis of aminoalcohol 17. 

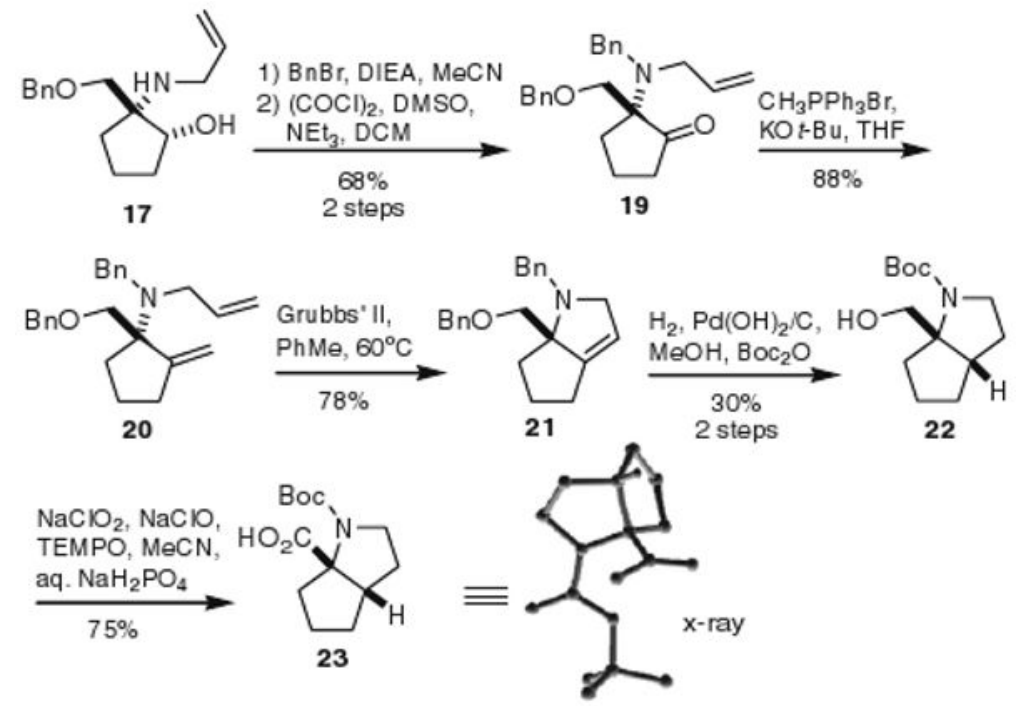

Scheme 4.

Synthesis and X-ray structure of (+)-N-Boc-bicycloproline (23). 